\title{
Electronic Marketplaces: A Cross-Industry Comparison
}

Dothang Truong, Embry-Riddle Aeronautical University, USA Mohammad Bhuiyan, Fayetteville State University, USA

\begin{abstract}
This research addresses the question of the potential growth of electronic marketplaces as an eentrepreneurship model. We will examine how electronic marketplaces are different among industry sectors from two major perspectives: the level of electronic marketplace usage and the level of e-readiness. The results of an empirical study conducted in the United States show that a wide range of industry sectors are currently prepared to use electronic marketplaces, and will use them in the future. These findings indicate a better chance for the growth of e-entrepreneurship as a solution for entrepreneurs in our current troubled economy.
\end{abstract}

Keywords: e-entrepreneurship; electronic marketplaces; e-readiness; industry sectors; empirical survey

\section{INTRODUCTION}



he constant and rapid growth of Internet technology in the networked economy has had a significant influence on various possibilities for developing innovative business ideas. In addition, the financial crisis has forced businessmen to seek ways to do business with higher efficiency and effectiveness-and Internet technology are a means for achieving these objectives. Hence, many new e-businesses have been created to provide online solutions for industries. The term 'e-entrepreneurship' describes the act of establishing new companies specifically in the networked economy (Kollmann, 2006; Matlay, 2004). Nowadays, many business operations (procurement, supply chain management, inventory management) can be done online, saving companies a great deal of time and money. Owing to these opportunities to save money, entrepreneurs in particular have shown significant interest in integrating electronic marketplaces into their business models (Rao et al., 2007; Truong, 2008).

Electronic marketplaces work as inter-organizational information systems that allow business partners to exchange business information, communicate, and interact through an electronic platform (Malone et al., 1987; Bakos, 1991). Several electronic marketplaces have shown significant success in their business, such as Covisint, FreeMarket, and WalMart Retail link. Nevertheless, the rapid proliferation of established electronic marketplaces along with the attendant challenges of using these platforms has made many client companies hesitant to adopt them (Truong and Jitpaiboon, 2007). Despite the great benefits of electronic marketplaces, risks such as the leaking of business information, and dealings with unknown business partners, together with high technical requirements and high financial investments of utilizing such marketplaces, have resulted in a lower number of electronic marketplace adopters. This, in turn, has threatened the growth of electronic marketplaces in the near future.

Many research studies have been conducted in the context of electronic marketplaces, but very little attention has been paid to the future of the electronic marketplace from the entrepreneurship point of view. Electronic marketplaces have been evolving and overcoming their disadvantages, but they still do not have a sufficient number of customers, especially certain B2B electronic marketplace platforms which require high investments. As the economy worsens and companies look for ways to cut costs, it is important to examine how different industry sectors react to the advent of electronic marketplaces. Surveys conducted by the European Commission (2007) and Forester Research (2000) have indicated that some industry sectors, such as electronics and communications, accept electronic marketplaces at a higher rate than others. However, these surveys did not get to the crux of the issue at hand, as they did not show what dimensions of electronic marketplaces are favorable or 
unfavorable to each industry sector. They also did not show to what extent companies in each sector were ready to adjust to the era of electronic trading.

The purpose of this research is to analyze the prospects of electronic marketplaces as a successful eentrepreneurship model in the near future by examining the perceptions of companies in various industry sectors to the potential of electronic marketplaces. Major research questions are: 1) What are the differences among industry sectors in using electronic marketplaces?; 2) How ready are companies in each industry sector to using electronic marketplaces? The answers for those research questions will provide us more knowledge about the future of electronic marketplaces from an e- entrepreneurship point of view. This research also has practical implications, as it will enable entrepreneurs in different industry sectors to reevaluate the value of electronic marketplaces and decide both whether or not they should open new e-businesses using this model, and what types of electronic marketplaces will be suitable for them.

The research is constructed as follows. First, the background of electronic marketplaces, categories, and literature review of their benefits and challenges will be provided. Then, the research hypotheses will be proposed. Next, the research methodology will be described along with the data collection process. The results of the hypothesis testing will be shown with the discussions. Finally, the conclusions are discussed with research implications, limitation, and future research.

\section{BACKGROUND OF ELECTRONIC MARKETPLACES}

\section{Introduction to Electronic Marketplaces}

Electronic marketplaces can be defined as inter-organizational platforms that enable companies to exchange business information, and complete transactions through the Internet (Bakos, 1991, Malone et al., 1987). Key players of electronic marketplaces are market makers, suppliers, and buyers. When customers use electronic marketplaces, all activities in the entire supply chain process, including searching for trading partners, requesting proposals, requesting quotes, searching for products and prices, ordering and replenishment, transportation, payment, shipment and inventory tracking, exchange of information, and communication between trading partners will all be done online. Accordingly, a significant amount of time and money will be saved through using this business model. Electronic marketplaces are important units in several industries because they promise to greatly improve economic efficiency, reduce margins between price and cost, and speed up complicated business deals. The services they provide will expand many customers' purchasing and selling abilities, and will make prices more dynamic and responsive to economic conditions (Feldman, 2000). Customers who expect to cut costs and increase both the efficiency and effectiveness of their business performance are the ones who benefit most from adopting electronic marketplaces. These potential benefits attract the attention of entrepreneurs who are seeking a successful business model in an economic downturn.

Electronic marketplaces are not homogeneous and can be implemented in various forms which have distinctive advantages and disadvantages. Electronic marketplaces can be categorized into three major types (Le, 2005; Truong, 2008; Truong and Bhuiyan, 2009):

1. Independent Trading Exchanges (ITXs): This is a many-to-many electronic marketplace which plays the role of an independent organization that connects buyers and sellers thru their electronic trading platform. This type of electronic marketplace usually does not require high start-up cost or a high level of information technology readiness. However, it does not provide a high level of collaboration between business partners. Security issues and a trust barrier are some of participants' main concerns (Truong, 2008).

2. Consortia Trading Exchanges (CTXs): This is a some-to-many electronic marketplace which has been established by dominant companies in a specific sector such as the automotive, chemical, or electronic industries. Participants can benefit from the high level of collaboration with business partners thru CTX's secured and sophisticated network. On the other hand, it is more expensive to set up and requires participants to meet certain technical requirements and pay high membership as well as trading fees. 
3. Private Trading Exchanges (PTXs): This is a one-to-many electronic marketplace which usually is set up by a dominant buyer or seller. This marketplace helps connect such buyers/sellers to all of their business partners, and allows them to complete all trading online. This is the most secure and advanced network, providing the highest level of collaboration between the dominant company and business partners. However, utilization of this type of electronic marketplace is limited to large companies with strong financial and technical resources.

\section{Electronic Marketplaces and Their Role in the Economy}

In order to examine the chances of success for electronic marketplaces, it is important to understand their role in the economy. In the current economic downturn, many industries are experiencing difficulties in their business. In its most recent report in February 2009, the Institute for Supply Management (ISM) surveyed eighteen manufacturing industries (Primary Metals; Wood Products; Electrical Equipment, Appliances \& Components; Furniture \& Related Products; Paper Products; Textile Mills; Fabricated Metal Products; Nonmetallic Mineral Products; Miscellaneous Manufacturing; Plastics \& Rubber Products; Chemical Products; Machinery; Transportation Equipment; Computer \& Electronic Products; Petroleum \& Coal Products; Printing \& Related Support Activities; Apparel, Leather \& Allied Products; and Food, Beverage \& Tobacco Products). None of them reported growth. Some typical responses about the economic downturn from these industries include: "Customers across the board are being very cautious about ordering any stock." (Transportation Equipment); "Business is very slow, some of which is due to seasonality, and some is due to the state of the economy." (Chemical Products); "Asia previously was over 50 percent of our business and is now close to zero." (Machinery); "Still seeing frequent attempts at increases while everything is reacting to an economy that is retracting." (Food, Beverage \& Tobacco Products); "Business slightly improved in February. May be the result of inventories finally coming into balance with lower demand." (Paper Products) (ISM Report, 2009).

Under these circumstances, electronic marketplaces may be one of the solutions for our troubled economy. The advent of electronic marketplaces has apparently changed the market in terms of search, price discovery, and trade settlement (Lee and Clark, 1996). Some electronic marketplaces such as electronic brokerages and electronic auctions are considered alternative market structures with higher efficiency and lower transactional costs. Electronic marketplaces which are based upon the Internet platform posses some substantial benefits for customers. Many studies have been undertaken to establish and verify the value generation model for electronic marketplaces. Conventional studies have used economic theories to explain the capability of electronic marketplaces to reduce the trading costs, search costs, and increase the access to the trading partners' database. Some more recent studies have emphasized the benefits of electronic marketplaces from the supply chain collaboration perspective. Le (2002) has analyzed the pros and cons of those studies and recommended two dimensions for the value proposition of electronic marketplaces: market aggregation and supply chain collaboration. These dimensions have been empirically tested in studies by Rao et al. (2007). Market aggregation refers to the utility of electronic marketplaces in overcoming market fragmentation, thus offering buyers more choices, more readily available information about product and suppliers, transparent prices, and lower transaction costs. Supply chain integration refers to the usefulness of the electronic marketplaces that enable market participants to build and deepen their business relationships for the purposes of improving individual business processes and overall supply chain performance.

The value propositions of electronic marketplaces make them an attractive business model for customers in many industries, especially in this difficult time, when companies across the board are trying to improve their business performance through cost reduction and better interaction with business partners, be they domestic or international. This will become an excellent opportunity for entrepreneurs who seek to open a new business in the networked economy.

Yet entrepreneurs need to be aware of some barriers created by electronic marketplaces. Rao et al. (2007) proposed two major challenges of using electronic marketplaces for business trading: financial risks and trust barriers. Financial risks refer to costs including initial development investments and recurring operating expenses. Trust barriers refer to constraints due to the uncertainties in safeguarding sensitive business information and in dealing with unknown business partners. Although customers may be negatively affected by these challenges, the degrees of the challenges are not homogeneous and depend on the various factors such as electronic marketplace 
type, company's size, and company's e-readiness. An exploratory study of these issues will help shed the light on this issue.

\section{RESEARCH QUESTIONS}

Despite the importance of electronic marketplaces as a model for e-entrepreneurship in the economy, no related empirical analysis has been found in the existing literature. The only empirical evidence we found were two surveys conducted by Forrester Research (2000) and European Commission (2007) in the e-business area. The Forrester Research (2000) reported on eight industries representing different levels of penetration for B2B ebusiness in general. The sectors included electronic and other sectors related to electrical products and communication industries at the higher end, as well as food, kinked products, and printing and publishing industries at the lower end. However, this report is very brief and out of date. In addition, the report addressed issues for ebusiness in general without specifically analyzing different business models, and furthermore did not reveal the impact of other important factors such as each company's size and level of e-readiness. In a more recent survey, the European Commission (2007) reported the number of companies ordering supply goods online from ten different industry sectors (food \& beverages, footwear, pulp \& paper, manufacturing, consumer electronics, shipbuilding \& repair, construction, tourism, telecommunication, hospital activities). The results showed that the manufacturing, electronics, and telecommunication sectors use electronic marketplaces to a significant degree, while sectors such as food, footwear, and paper use electronic marketplaces to a much lesser extent. Although those surveys share common results, they also share many similar shortcomings. First, both are industrial empirical surveys, and thus are not based upon a theoretical foundation as well as research framework. They simply reported the responses of a number of companies in each industry sector responding to certain questions. The survey by Forrester Research is very outdated. The survey by the European Commission is more recent and showed the e-readiness of industries at some levels. Nonetheless, neither survey differentiates between different types of electronic marketplaces.

Due to the lack of theory and evidence in related research issues, we seek to conduct an exploratory research to examine the chances of success for the use of electronic marketplaces as an e-entrepreneurship model in different industry sectors. Accordingly, instead of developing research hypotheses on the foundation of strong literature, we raise several research questions based upon the related literature review and analysis of economic trends.

First, in order to analyze the potential of electronic marketplaces in industry sectors, there is a need to examine how industry sectors perceive the importance of electronic marketplaces and the extent to which electronic marketplaces are accepted by customers in industry sectors. The above surveys indicated that customers in industry sectors such as electronic products and communication would accept electronic marketplaces at a higher level because their products are better suited for online transactions. On the other hand industry sectors such as food, paper, and publishing are at the lower end in using electronic marketplaces, due to the characteristics of their products. For example, the products in the food industry are more perishable, thereby requiring faster shipping time Thus, companies in this industry sector might have had little interest in online transactions because they did not see the potential demand. Although this argument might have been valid at one time, Internet technology has improved significantly since then, and e-commerce sales have grown significantly. It can now be seen that all types of products in the market can be offered online. Hence, it can be argued that the differences among industry sectors are getting narrower in term of adopting electronic solutions for business processes. In addition, since each type of electronic marketplace has distinctive benefits and challenges, the perception of companies in each industry sector toward using electronic marketplaces may not be the same. Large companies with strong financial and technical resources and with high expectation of the security and collaboration capabilities may prefer PTXs or CTXs (Rao et al., 2007; Truong, 2008). On the other side, ITXs may be better suited for smaller companies since this they do not require high start-up investment nor high technical requirements. These discussions lead to the following research question

\section{Question 1: Are there significant differences in regard to electronic market usage among industry sectors?}

The results of surveys mentioned above also revealed another side of the issue: whether companies in an industry sector are ready to adopt an electronic solution such as electronic marketplaces. According to Forester 
Research (2000), industries such as paper, publishing, and food were considered a lower end compared to others (electronic, electrical, communication) with regard to their ability to use and exploit features and benefits of electronic marketplaces. The survey was conducted at the time when very few large companies actually conducted business transactions online. Again, times have changed, as the substantial improvement of Internet technology has allowed such companies to provide higher level of ease and usefulness. Hence, it is easier for any company to use electronic solutions which are now available globally. The European Commission report shows that there are no differences among industry sectors in term of broadband Internet access and remote access to company networks (2007).

Although it is true that the companies which are more ready for the networked economy will be more likely to adopt electronic marketplaces (Truong, 2008), that does not necessarily mean that some industry sectors are more ready than others. Electronic marketplaces, especially ones like CTXs or PTXs, require customers to gain a certain level of experience in using IT/IS in business transactions before they can use this new form of exchanges. The results of this research will help to reveal the differences among industry sectors with regard to this matter. Companies' e-readiness in the networked economy has been studied in current research which has measured ereadiness by three major dimensions: IT usage for business transactions, Internet usage for business transaction, and IS usage for enhancing SCM (Ttruong, 2008). These discussions lead to the second research question

\section{Question 2: Are there significant differences in regard to the level of e-readiness among industry sectors?}

\section{RESEARCH METHODOLOGIES}

\section{Data Collection: Web-Based Survey}

In order to answer the research questions, a large-scale survey was conducted. In our study, which focused on electronic marketplaces, we concentrated on these eight major industry sectors as suggested by Forrester Research: Food, Paper, Printing \& Publishing, Rubber and Plastic, Fabricated Metal, Electronics, Transportation, and Communication. The data for this study was collected through a Web-based survey in the United States. A mailing list was provided by The Institute for Supply Management, and the survey received 359 responses.

\section{Profile of Respondents and Industry Sectors}

Survey respondents include vice presidents for materials (6 per cent), directors of procurement (13 per cent), purchasing managers (74 per cent) and "others" (7 per cent). Their organizations range widely in size, as measured by their annual sales and number of employees. However, respondents from larger organizations are proportionally better represented: 37 per cent from organizations with $\$ 1$ billion or more in annual sales versus 6 per cent with less than $\$ 10$ million, 20 per cent from those with more than ten thousand employees compared to 11 per cent with fewer than 100, and 43 per cent from organizations with over $\$ 100$ million in purchasing budget versus 5 per cent below $\$ 1$ million.

We also look at the profile of industry sectors. Figure 1 shows the number of responses in each industry sector, with the highest responses fall in the electronics sector, followed by communication and food sector. Printing $\&$ publishing and rubber \& plastic sectors provide fewer responses.

Tables 1 and 2 show the annual sales and number of employees by industry sector. Sectors such as communication, transportation, and electronics are represented by a number of large companies (more than $41 \%$ ) with $\$ 1$ billion in annual sales or more, while the rubber \& plastic and fabricated metal sectors are mostly represented by smaller companies (more than 56\%) with the annual sale between $\$ 10$ million and $\$ 100$ million. With regard to number of employees, more than $30 \%$ of companies in communication and electronics sectors more than 10,000 employees. Similarly, the majority of companies (more than $75 \%$ ) in rubber \& plastic and fabricated metal sectors have less than 1,000 employees. Food, paper, and printing \& publishing are at a moderate level, from both the perspectives of annual sales and number of employees. The diversity of responding companies among industry sectors adds further value to the results of our exploratory study. 


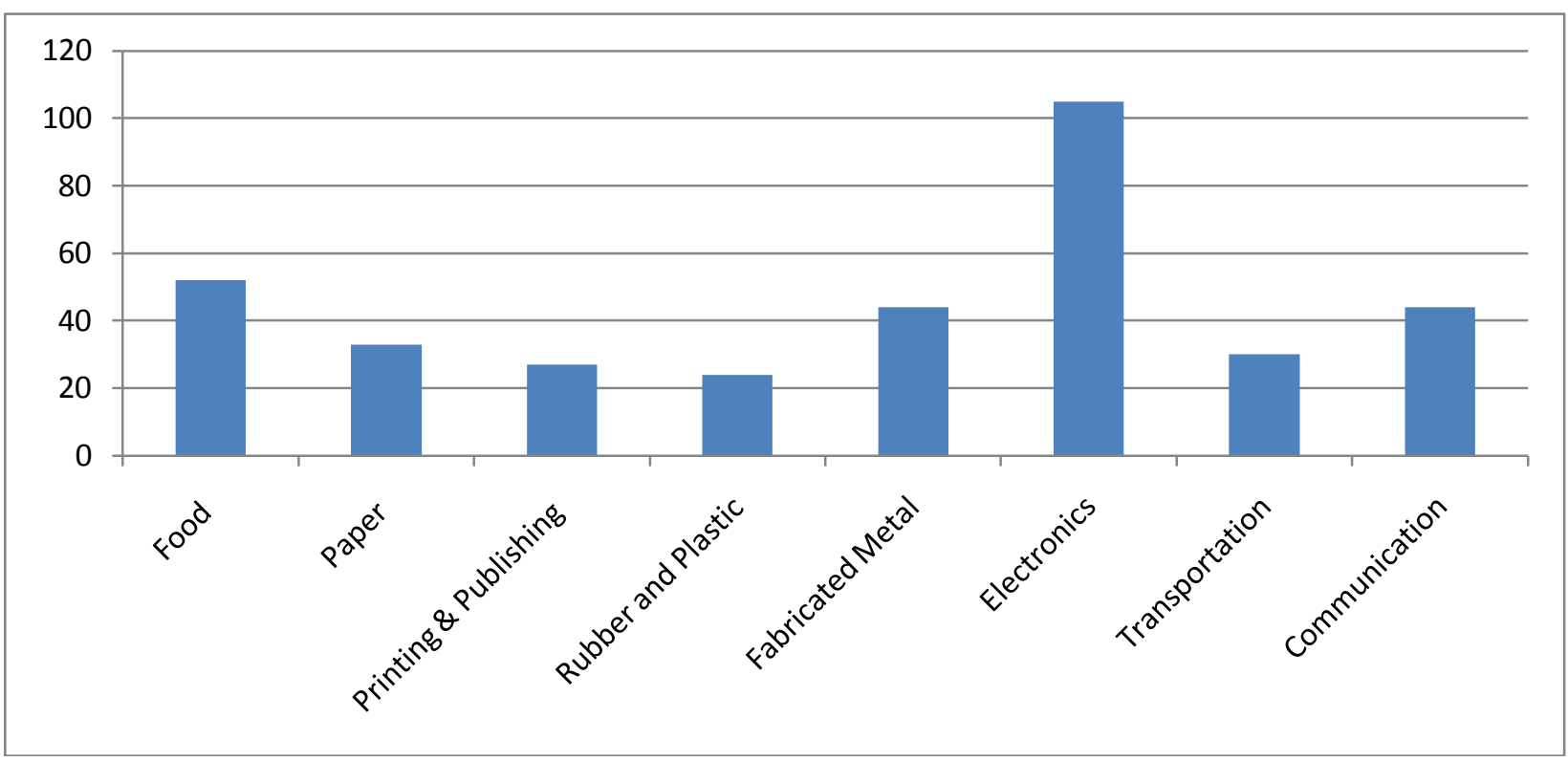

Figure 1: Reponses by Industry Sectors

Table 1: Annual Sale by Industry Sector

\begin{tabular}{|c|c|c|c|c|}
\hline \multirow[b]{2}{*}{ Industry Sectors } & \multicolumn{4}{|c|}{ Annual sale } \\
\hline & Under $\$ 10$ million & $\begin{array}{l}\$ 10 \text { million to } \\
\$ 100 \text { million }\end{array}$ & $\begin{array}{c}\$ 100 \text { million to } \\
<\$ 1 \text { billion }\end{array}$ & Over $\$ 1$ billion \\
\hline Food and Kindred Products & $11.5 \%$ & $23.1 \%$ & $26.9 \%$ & $38.5 \%$ \\
\hline Paper and Allied Products & $10.5 \%$ & $21.1 \%$ & $36.8 \%$ & $31.6 \%$ \\
\hline Printing and Publishing & $0.0 \%$ & $0.0 \%$ & $100.0 \%$ & $0.0 \%$ \\
\hline Rubber and Miscellaneous Plastic Products & $0.0 \%$ & $56.3 \%$ & $31.3 \%$ & $12.5 \%$ \\
\hline Fabricated Metal Products & $10.7 \%$ & $57.1 \%$ & $28.6 \%$ & $3.6 \%$ \\
\hline Electronic and Other Equipment & $2.9 \%$ & $27.1 \%$ & $27.1 \%$ & $42.9 \%$ \\
\hline Transportation Equipment & $11.8 \%$ & $23.5 \%$ & $23.5 \%$ & $41.2 \%$ \\
\hline Communication & $3.3 \%$ & $16.7 \%$ & $33.3 \%$ & $46.7 \%$ \\
\hline
\end{tabular}

Table 2: Number of Employees by Industry Sector

\begin{tabular}{|l|c|c|c|c|c|}
\hline \multirow{2}{*}{\multicolumn{1}{c|}{ Industry Sectors }} & \multicolumn{5}{c|}{ Number of Employees } \\
\cline { 2 - 7 } & Up to 100 & $\mathbf{1 0 1}$ to 250 & $\mathbf{2 5 1}$ to 1,000 & $\mathbf{1 , 0 0 1}$ to 10,000 & Over 10,000 \\
\hline Food and Kindred Products & $22.5 \%$ & $7.5 \%$ & $20.0 \%$ & $37.5 \%$ & $12.5 \%$ \\
\hline Paper and Allied Products & $12.0 \%$ & $20.0 \%$ & $16.0 \%$ & $24.0 \%$ & $28.0 \%$ \\
\hline Printing and Publishing & $0.0 \%$ & $4.5 \%$ & $36.4 \%$ & $50.0 \%$ & $9.1 \%$ \\
\hline Rubber and Miscellaneous Plastic Products & $14.3 \%$ & $33.3 \%$ & $28.6 \%$ & $14.3 \%$ & $9.5 \%$ \\
\hline Fabricated Metal Products & $28.2 \%$ & $23.1 \%$ & $35.9 \%$ & $7.7 \%$ & $5.1 \%$ \\
\hline Electronic and Other Equipment & $5.0 \%$ & $10.0 \%$ & $30.0 \%$ & $25.0 \%$ & $30.0 \%$ \\
\hline Transportation Equipment & $0.0 \%$ & $9.1 \%$ & $27.3 \%$ & $45.5 \%$ & $18.2 \%$ \\
\hline Communication & $0.0 \%$ & $0.0 \%$ & $30.6 \%$ & $36.1 \%$ & $33.3 \%$ \\
\hline
\end{tabular}




\section{Measurement instruments}

Research questions involve two major measurement instruments: electronic marketplace usage and ereadiness. The level of electronic marketplace usage can be measured by a single item which evaluates the current level of usage using 5-point Likert scale. In order to examine the usage from various perspectives, we measure the usage level of three types of electronic marketplaces: ITXs, CTXs, and PTXs. As for the level of e-readiness, we use the measurement instruments developed by Truong (2008). These instruments measure e-readiness from three dimensions: information technology usage, Internet usage, and information system usage for supply chain management. These instruments have been tested empirically using factor analysis.

\section{RESULTS AND DISCUSSIONS}

\section{Electronic Marketplace Usage by Industry sector}

Table 3 shows the descriptive statistics of electronic marketplace usage by industry sector. The mean and standard deviation are calculated for each type of electronic marketplace. Figure 2 shows the mean of electronic marketplace usage in graphic form (bar chart). Finally, MANOVA test was conducted to examine the significance of differences among industries. Dependent variables are the levels of ITX, CTX, and PTX usage. The independent variable is industry, which is comprised of eight different sectors. Table 4 shows the contrast test results for the MANOVA test along with the significance level.

Overall, the average level of usage is not very high (the mean values in Table 3), indicating that main industries continue to hesitate at the prospect of moving towards using electronic marketplaces. . However, the high standard deviation shows a high variation in the level of usage among companies. Across industries, it can be seen that industries which have a higher level of electronic marketplace usage include paper, electronic, transportation, and communication. However, the differences are generally not significant (Table 4). Only three significant differences can be found: Food vs. Paper, Printing \& Publishing vs. Rubber \& Plastic, and Rubber \& Plastic vs. Fabricated Metal; all three fall in the category of PTX usage. Although other contrast tests resulted in insignificant differences, we still can observe some variation visually from the bar chart in Figure 2. It appears that two industries with lower levels of electronic marketplace usage are Food and Rubber \& Plastic. Industries that were considered low-end in Forester Research (2000) (Paper and Printing \& Publishing) have shown great improvement and their usage level is nearly at the same level as other so-called high-end industries such as Electronics.

We also can see that PNTs have been used at a higher level compared to ITXs and CTXs. These results confirm the beneficial characteristics of PTXs and indicate the potential dominance of this type of electronic marketplace in the near future.

Table 3: Descriptive Statistics of Electronic Marketplace Usage by Industry sector

\begin{tabular}{|l|c|c|c|c|c|c|}
\hline \multicolumn{2}{|c|}{ Industry } & \multicolumn{2}{c|}{ ITX Usage } & \multicolumn{2}{c|}{ CTX Usage } & \multicolumn{2}{c|}{ PTX Usage } \\
\hline Food & Mean & Std. Deviation & Mean & Std. Deviation & Mean & Std. Deviation \\
\hline Paper & 1.39 & .759 & 1.31 & .619 & 1.41 & .788 \\
\hline Printing \& Publishing & 1.70 & 1.119 & 1.50 & .861 & 1.97 & 1.351 \\
\hline Rubber and Plastic & 1.33 & .565 & 1.21 & .415 & 1.75 & 1.225 \\
\hline Fabricated Metal & 1.14 & .351 & 1.18 & .501 & 1.14 & .351 \\
\hline Electronics & 1.50 & 1.038 & 1.38 & .705 & 1.68 & 1.207 \\
\hline Transportation & 1.65 & 1.195 & 1.61 & 1.104 & 1.67 & 1.164 \\
\hline Communication & 1.70 & 1.103 & 1.70 & .953 & 1.81 & 1.302 \\
\hline
\end{tabular}




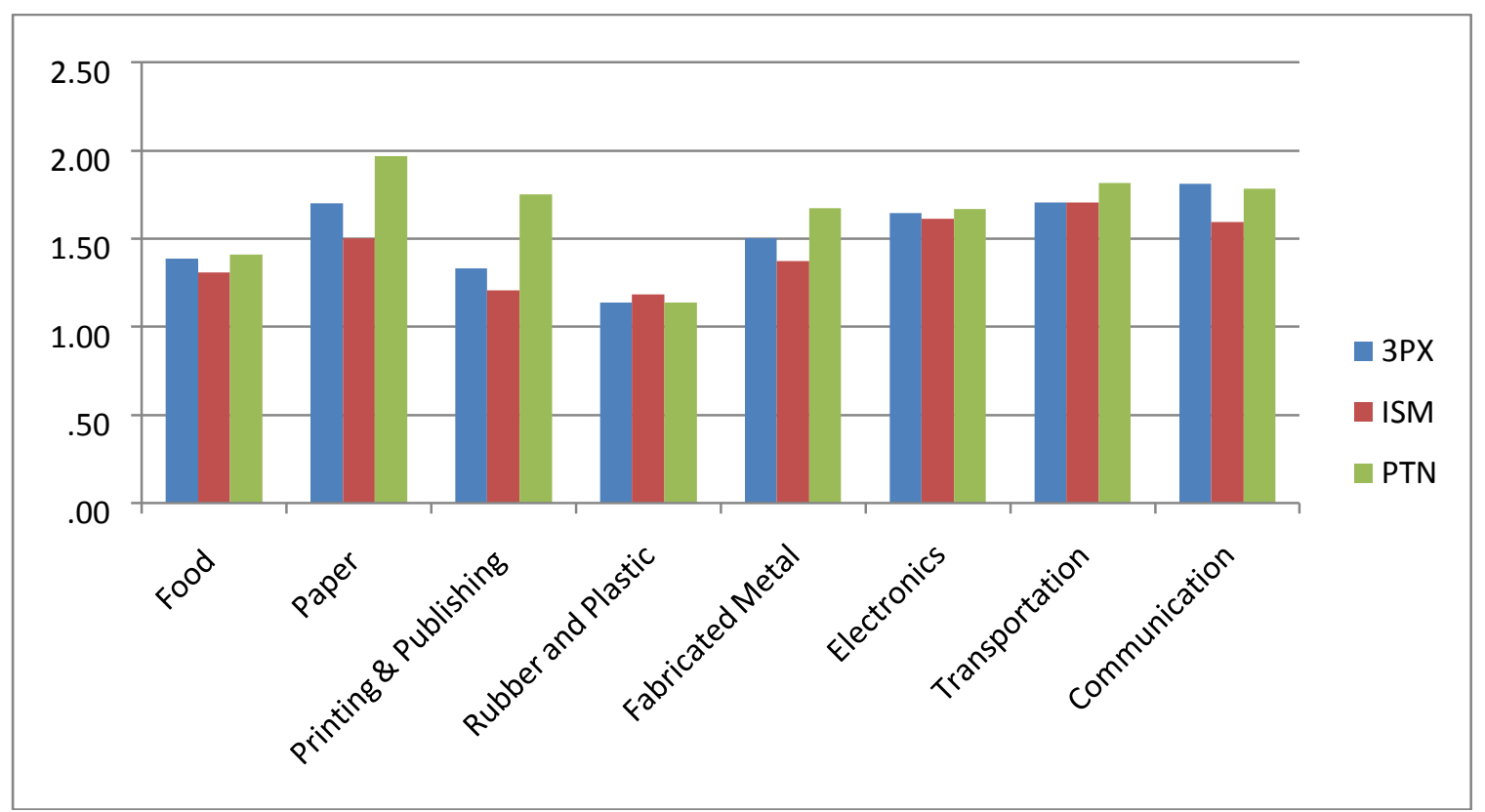

Figure 2: Electronic Marketplace Usage by Industry sector

Table 4: MANOVA Results for the Electronic Market Usage across Industries

\begin{tabular}{|l|l|c|c|c|}
\hline \multirow{2}{*}{ Contrast } & \multicolumn{2}{c|}{ Dependent Variable } \\
\cline { 2 - 5 } & & \multicolumn{1}{c|}{ ITX usage } & CTX usage & \multicolumn{1}{c|}{ PTX usage } \\
\hline \multirow{2}{*}{ Food vs. Paper } & Contrast Estimate & -.312 & -.194 & -.559 \\
\cline { 2 - 5 } & Sig & .204 & .353 & $.031^{* *}$ \\
\hline \multirow{2}{*}{ Paper vs. Printing \& Publishing } & Contrast Estimate & .367 & .292 & .217 \\
\cline { 2 - 5 } & Sig & .207 & .237 & .478 \\
\hline \multirow{2}{*}{ Printing \& Publishing vs. Rubber \& Plastic } & Contrast Estimate & .197 & .027 & .614 \\
\cline { 2 - 5 } & Sig & .529 & .921 & $.063^{*}$ \\
\hline Rubber \& Plastic vs. Fabricated Metal & Contrast Estimate & -.364 & -.193 & -.539 \\
\cline { 2 - 5 } & Sig & .196 & .419 & $.070^{*}$ \\
\hline Fabricated Metal vs. Electronics & Contrast Estimate & -.145 & .238 & .008 \\
\cline { 2 - 5 } & Sig & .469 & .163 & .968 \\
\hline Electronics vs. Transportation & Contrast Estimate & -.145 & .238 & .008 \\
\cline { 2 - 5 } & Sig & .469 & .163 & .968 \\
\hline Transportation vs. Communication & Contrast Estimate & -.106 & .108 & .029 \\
\cline { 2 - 5 } & Sig & .685 & .625 & .916 \\
\hline
\end{tabular}

** significant at $\mathrm{p}<0.05$

* significant at $\mathrm{p}<0.1$

\section{E-readiness by Industry sector}

Table 5 shows the descriptive statistics of e-readiness by industry sector. The mean and standard deviation are calculated for each type of electronic marketplace. Figure 3 shows the mean of e-readiness in graphic form (bar chart). Finally, MANOVA test was conducted to examine the significance of differences among industries. Dependent variables are the level of IT usage, Internet usage for transactions, and information systems usage for SCM. The independent variable is industry, which is comprised of eight different sectors. Table 6 shows the contrast test results for MANOVA test along with the significance level.

The results of this section will help us to explain the differences observed in the previous section. As discussed before, a key factor that affects the rate of adoption of electronic marketplaces by companies is the technical requirements of the electronic platform. If a company is more e-ready, it will be more likely to use and 
exploit the benefits of electronic marketplaces. Overall, companies in electronics, transportation, and communication sectors have more experience in using IT, Internet, and information systems to facilitate their business transactions. We also can see that for most sectors, the level of Internet usage is lower than others. This is understandable because Internet users experience many difficulties with security and stability issues. On the other hand, the use of IT such as EDI and RFP systems, which have been in the market for a longer time, is preferrable because they provide users with more secure and stable transactions (Truong and Jitpaiboon, 2008). The results of the European Commission report (2007) confirm this conclusion. Additionally, most of the companies in those industry sectors have been dealing with supply chain management (SCM) performance which is linked to their business performance. Information systems have been used for a longer time to support SCM performance. This explains the higher usage level of information systems for SCM.

Finally, even though we see some differences in term of e-readiness, these differences are not very significant, and are clearly limited to a few industry sectors. It appears that the only significant contrast is between fabricated metal and electronics. It is worth noting that industry sectors considered to be "low-end," such as Food, Paper, Printing \& Publishing, and Rubber \& Plastic, show a reasonable level of e-readiness compared to high-end sectors such as electronics and communication. These findings indicate that most industry sectors have recognized the importance of using electronic tools in their business transaction. This further highlights the potential for growth of electronic marketplace usage in the future.

Table 5: Level of E-Readiness by industry sector

\begin{tabular}{|l|c|c|c|c|c|c|}
\hline & \multicolumn{2}{|c|}{ IT usage } & \multicolumn{2}{c|}{ Internet usage } & \multicolumn{2}{c|}{$\begin{array}{c}\text { Information systems usage for } \\
\text { SCM }\end{array}$} \\
\hline \multicolumn{1}{|c|}{ Industry sector } & Mean & Std. Deviation & Mean & Std. Deviation & Mean & Std. Deviation \\
\hline Food & 2.6538 & .94632 & 2.1875 & .85014 & 3.0529 & 1.12278 \\
\hline Paper & 2.5964 & .92023 & 2.1328 & .90247 & 2.6563 & 1.09388 \\
\hline Printing \& Publishing & 2.6759 & .89016 & 2.4815 & .81431 & 2.8426 & .85527 \\
\hline Rubber and Plastic & 3.0521 & 1.31045 & 2.4653 & 1.00839 & 3.0417 & 1.20836 \\
\hline Fabricated Metal & 2.7837 & 1.00153 & 2.5020 & 1.06599 & 2.6091 & 1.11492 \\
\hline Electronics & 3.0866 & 1.17382 & 2.3576 & 1.10804 & 3.1383 & 1.28245 \\
\hline Transportation & 3.2472 & .98199 & 2.4306 & 1.11333 & 3.3611 & 1.08528 \\
\hline Communication & 3.3236 & 1.09112 & 2.7539 & 1.15927 & 3.2868 & 1.36668 \\
\hline
\end{tabular}



Figure 3: Level of E-Readiness by Industry sector 
Table 6: MANOVA Results for the E-readiness across Industry sector

\begin{tabular}{|l|l|c|c|c|}
\hline \multirow{2}{*}{ Contrast } & & \multicolumn{3}{c|}{ Dependent Variable } \\
\cline { 2 - 5 } & & IT usage & Internet usage & $\begin{array}{c}\text { Information systems } \\
\text { usage for SCM }\end{array}$ \\
\hline \multirow{2}{*}{ Food vs. Paper } & Contrast Estimate & .057 & .055 & .397 \\
\cline { 2 - 5 } & Sig & .810 & .814 & .138 \\
\hline \multirow{2}{*}{ Paper vs. Printing \& Publishing } & Contrast Estimate & -.080 & -.349 & -.186 \\
\cline { 2 - 5 } & Sig & .775 & .197 & .548 \\
\hline \multirow{2}{*}{$\begin{array}{l}\text { Printing \& Publishing vs. Rubber \& } \\
\text { Plastic }\end{array}$} & Contrast Estimate & -.376 & .016 & -.199 \\
\cline { 2 - 5 } $\begin{array}{l}\text { Rubber \& Plastic vs. Fabricated } \\
\text { Metal }\end{array}$ & Sig & .209 & .955 & .550 \\
\hline \multirow{2}{*}{ Fabricated Metal vs. Electronics } & Contrast Estimate & .268 & -.037 & .433 \\
\cline { 2 - 5 } & Sig & .326 & .889 & .155 \\
\hline \multirow{2}{*}{ Electronics vs. Transportation } & Sig &. .303 & .144 & -.529 \\
\hline \multirow{2}{*}{\begin{tabular}{l} 
Transportation vs. Communication \\
\cline { 2 - 5 }
\end{tabular}} & Contrast Estimate & -.161 & .445 & $.015^{* *}$ \\
\cline { 2 - 5 } & Sig & .468 & .733 & -.223 \\
\cline { 2 - 5 } & Sig &. .076 & -.323 & .366 \\
\hline
\end{tabular}

** significant at $\mathrm{p}<0.05$

* significant at $\mathrm{p}<0.1$

\section{Potential Growth of Electronic Marketplaces}

As more companies become e-ready, they will be more likely to use electronic marketplaces (Truong, 2008), and if they are already using them, to use them to a greater extent. From that point of view, electronic marketplaces have similar chances to grow in rates of adoption by most industry sectors because levels of ereadiness among such sectors do not vary significantly. The potential growth of electronic marketplaces as an eentrepreneurship model can be seen clearly as we consider the size and years in business of companies in various industry sectors. Since high-end industry sectors have already attracted sufficient customers to e-entrepreneurship, we will focus more on low-end sectors. Table 7 shows the average of company size (in term of number of employees) in a scale 1 to 5 and the number of years in business. It can be seen that in low-end sectors such as paper and printing, the average company size is as large as high-end sectors (electronics, communication). The larger the company size, the greater the volume of their online transactions. Hence, if they increasingly begin using electronic marketplaces for their transactions, it will generate more revenues for e-entrepreneurs.

Additionally, paper and printing sectors have some of the longest-operating companies in the business world. This number implies that those companies have established strong reputations and relationships with business partners. When these companies adopt electronic marketplaces for their business, they will thus attract their partners to do the same, bringing more potential customers to e-entrepreneurs. Thus, the potential growth of electronic marketplaces in these sectors should not be underestimated, and e-entrepreneurs should pay more attention to companies in these sectors in the future.

Table 7: Company size and years in business

\begin{tabular}{|l|c|c|}
\hline \multicolumn{1}{|c|}{ Industry sector } & Average size (in the scale 1 to 5) & Number of years in business \\
\hline Food & 3.0 & 47.8 \\
\hline Paper & 3.5 & 78.1 \\
\hline Printing \& Publishing & 3.5 & 70.4 \\
\hline Rubber and Plastic & 2.8 & 41.0 \\
\hline Fabricated Metal & 2.2 & 45.6 \\
\hline Electronics & 3.5 & 43.1 \\
\hline Transportation & 3.4 & 48.6 \\
\hline Communication & 4.0 & 36.7 \\
\hline
\end{tabular}






Figure 4: Company size by industry sector

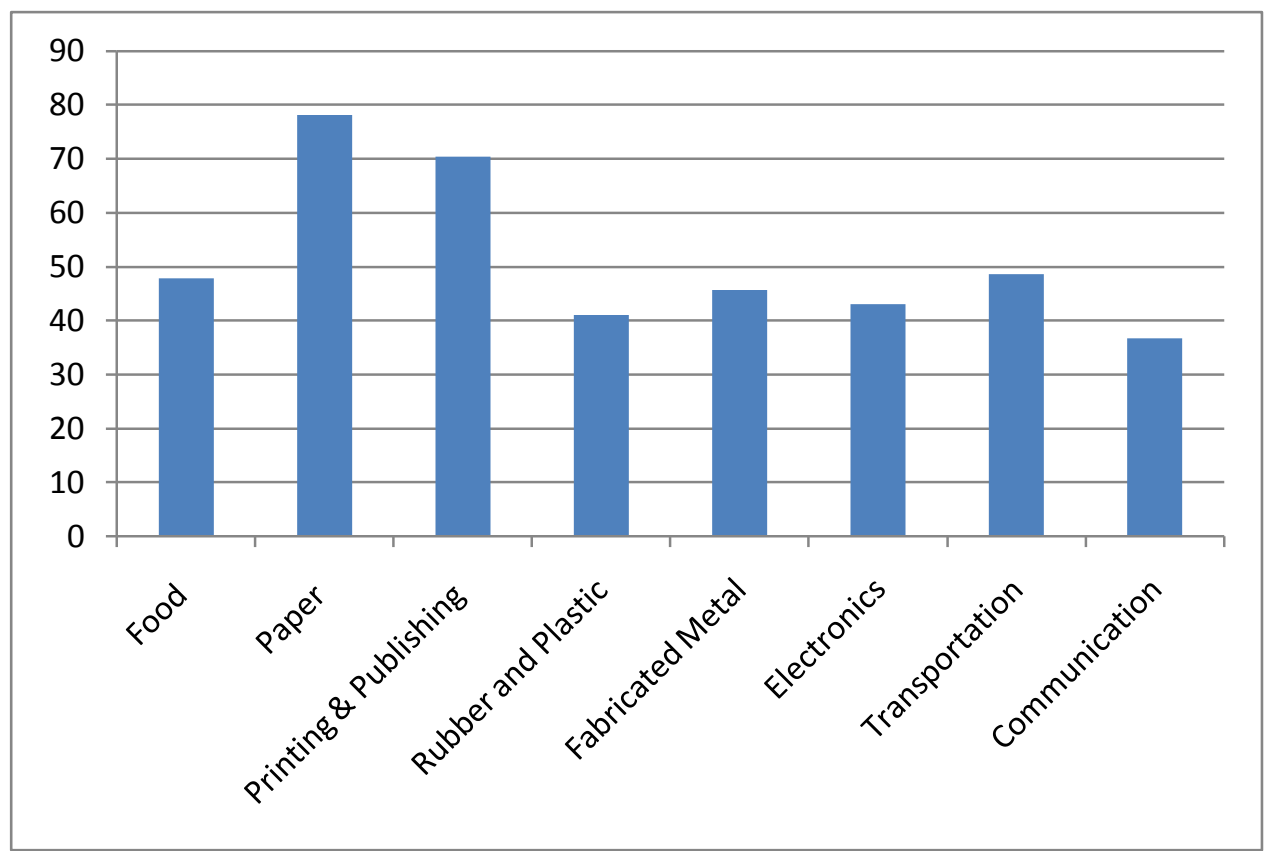

Figure 5: Years in business by industry sector

\section{CONCLUSIONS}

This research addresses questions about the potential growth of electronic marketplaces as an eentrepreneurship model. We examined how electronic marketplaces are different among a variety of industry sectors from two major perspectives: the level of electronic marketplace usage and the level of e-readiness. Our findings 
have some major contributions to the literature on this topic. In contrast to previous studies, this research found that the differences among industry sectors are not very significant. Compared to some high-end industry sectors such as electronics, transportation, and communications, other sectors such as paper which were considered low-end also show some growth in the e-readiness and the interest in using electronic marketplaces for their business transactions. Thus, the success of electronic marketplaces comes from a wide range of industry sectors. These findings will help researchers to shape the future development of e-entrepreneurship through electronic marketplace solutions. The results also confirm the important role of PTXs as the dominant type of electronic marketplace.

Practitioners will also benefit from this research since they can use these results to start up successful eentrepreneurship models in the form of electronic marketplaces. As the Internet becomes more popular, affordable, and easier to use, more companies in most industry sectors will move toward using this e-entrepreneurship model which will enable them to enhance their performance and improve the effectiveness and efficiency of their business processes.

This research still has some limitations. First, it is exploratory study, and as such no research model and hypotheses have been developed. Second, due to the constraints of using limited survey data, the conclusions of this research are limited to US companies. Third, the research is limited to only eight industry sectors, and needs to be expanded in order to draw broader conclusions. Future research should focus on key success factors for eentrepreneurship models, and a cross-country survey should be conducted.

\section{AUTHOR INFORMATION}

Dr. Dothang Truong is the Associate Professor of Doctoral Studies at Embry Riddle Aeronautical University, Florida. He received a Ph.D. in Manufacturing Management from the University of Toledo. His research interests include e-commerce, RFID and supply chain integration, cloud computing, Web 2.0., and logistics. His publications appear in many academic journals such as Electronic Markets, Journal of Organizational Computing and Electronic Commerce, Journal of Enterprise Information Management, Industrial Marketing Management, International Journal of Enterprise Information Systems.

Dr. Mohammad Bhuiyan is the Endowed Chair Professor of Entrepreneurship and the Director of the Center for Entrepreneurship at Fayetteville State University. $\mathrm{He}$ is the founding national director of the national entrepreneurship program for Historically Black Colleges and Universities (HBCUs). He is also the President \& CEO of Global Trading and Consulting, Inc. Dr. Bhuiyan works with 2006 Nobel Peace Prize Winner Prof. Muhammad Yunus to promote Social Business idea in USA. He has lived in, worked and traveled to over 35 countries. Dr. Bhuiyan has been named to the Who's Who in the World and Who's Who in America.

\section{REFERENCES}

1. $\quad$ Bakos, J.Y. (1991). A Strategic Analysis of Electronic Marketplaces, MIS Quarterly, September, 295-310.

2. $\quad$ Bakos, J.Y. (1991). A Strategic Analysis of Electronic Marketplaces, MIS Quarterly, September, 295-310.

3. European Comission (2007), The European e-Business Report. Portrait of e-business in 10 sectors of the EU economy. $5^{\text {th }}$ Synthesis Report of the e-Business W@ @tch. 2006/07 edition. URL: http://www.ebusinesswatch.org/key reports/documents/EBR06.pdf

4. $\quad$ Feldman, S. (2000). Electronic Marketplaces, IEEE Internet Computing, July-August, 93-95

5. Forrester Research (2000). EMarketplaces Boost B2B Trade, Forrester Research, February, 1-12. URL: http://www.forrester.com.

6. $\quad$ ISM Report (2009). Institute for Supply Management Report on Business, February. URL: http://www.ism.ws/ISMReport/MfgROB.cfm?navItemNumber=12942

7. Kollmann T. (2006). What is e-entrepreneurship? - Fundamentals of company founding in the net economy, International Journal of Technology Management, 33(4), 322 - 340

8. Le, T.T (2005). Business-to-business electronic marketplaces: Evolving business models and competitive landscape, International Journal of Services, Technology and Management, 6(1), 1-40.

9. Le, T.T. (2002). Pathways to Leadership for Business-to-Business Electronic Marketplaces, Electronic Markets, 12(2), 112-119. 
10. Lee, H.G. and Clark, T.H. (1996). Impacts of the electronic marketplace on transaction cost and market structure, International Journal of Electronic Commerce, 1(1), 127-149

11. Malone, T.W., Yates, J., and Benjamin, R.I. (1987). "Electronic Markets and Electronic Hierarchies", Communication of the ACM, 30(6), 484-497.

12. Matlay, H. (2004) 'E-entrepreneurship and small e-business development: towards a comparative research agenda', Journal of Small Business and Enterprise Development, 11, 408-414.

13. Rao, S., Truong, D., Le, T.T., and Senecal, Sylvain (2007). How Buyers' Expected Benefits, Perceived Risks, and e-Business Readiness Influence their E-Marketplace Usage, Industrial Marketing Management, 36(8), 1035-1045.

14. Truong, D. \& Bhuiyan, M (2009). E-Market and Entrepreneurship, International Journal of Entrepreneurship, 13, 1-22.

15. Truong, D. \& Jitpaiboon, T. (2008). How IT-Purchasing Preparedness Facilitates E-Marketplace Usage, Journal of Enterprise Information Management, 21(1), 198-218.

16. Truong, D. (2008). An Empirical Study of Business-To-Business Electronic Marketplace Usage: The Impact of Buyers' E-Readiness, Journal of Organizational Computing and Electronic Commerce, 18(2), $112-130$. 


\section{NOTES}

